\title{
The somatic genetic architecture of human cancer: heterogeneity and the challenges for translational medicine
}

\author{
Andy Futreal \\ From 2012 Sino-American Symposium on Clinical and Translational Medicine (SAS-CTM) \\ Shanghai, China. 27-29 June 2012
}

\begin{abstract}
Advances in sequencing technology have led to an unprecedented opportunity to characterize the genomes of human cancers. Our work has been focused on characterizing intra- and intertumoral heterogeneity in several tumor types. Work on breast cancer has revealed substantial complexity of operative cancer genes, with marked diversity between cancers revealed by exome sequencing. Further work in both renal and breast cancer has begun to define the architecture of intratumoral heterogeneity revealing evidence for substantial branched and, in some cases, convergent evolution within the same tumors. These data and others, particularly as they relate to the challenges of translation and genomics-base medicine will be discussed.
\end{abstract}

Published: 17 October 2012

doi:10.1186/1479-5876-10-S2-A7

Cite this article as: Futreal: The somatic genetic architecture of human cancer: heterogeneity and the challenges for translational medicine.

Journal of Translational Medicine 2012 10(Suppl 2):A7.
Submit your next manuscript to BioMed Central and take full advantage of:

- Convenient online submission

- Thorough peer review

- No space constraints or color figure charges

- Immediate publication on acceptance

- Inclusion in PubMed, CAS, Scopus and Google Scholar

- Research which is freely available for redistribution 